\title{
Modeling material flows as basic tool for enhancing company's efficiency during crisis
}

\author{
Olga Chudnova \\ Engineering school of the Far Eastern Federal University \\ FEFU \\ Vladivostok, Russia \\ Chudnova.oa@dvfu.ru
}

\author{
Elena Lubchenko \\ Lebedev Physical Institute of the Russian Academy of \\ Sciences (LPI RAS) \\ Moscow, Russia \\ lyubchenko@sci.lebedev.ru
}

\begin{abstract}
The article reviews the problems, emerging while planning, managing and evaluating the efficiency of material flows of enterprises, identifies and justifies the necessity of using integrated platform of management on the basis of systems and process theories. Moreover, the article provides the conceptual framework of models of systems decomposition and types of processes description and distinguishes the key steps for developing an integrated model of material flows. In addition, the article describes how the model of material flows, based on the integrated platform with the use of SADT- and ARIStechnologies, may be adapted in practice and shows the viability of developed models, collected in the albums of processes. The material flow model will provide an opportunity to conduct indepth analysis and point out some details, which remain unnoticed by employees as well as by management team, so that it will help to identify problem areas and enhance the quality.
\end{abstract}

Keywords-Material flows, processes-flows, systems theory, process theory, dynamic stability, enhancement of efficiency, integrated platform/integrated platform of management, SADTtechnologies, ARIS-technologies, the album of processes, quality control, process approach, system approach to management, "ASIS" model, "TO-BE" model.

\section{INTRODUCTION}

Nowadays in order to be competitive, companies have to be mobile, dynamically stable and possess a high functional response. Taking into account current economic situation, companies spend a lot of recourses on developing those features, while management teams of those companies try to minimize costs and maximize benefits.

The authors suppose that the use of approach, based on integrated use of systems theory and processes theory, may become a solution for this problem. It is possible to claim that every company may be presented as a permanently changing dynamic system of material flows. To clarify that statement, let us consider the notion of the system itself.

The notion of "system" is quite multifaceted and is used in all the academic fields. According to one of the founders of systems theory, Austrian scientist Ludwig von Bertalanffy, the system is a "set of interconnected and interacting components (actions)". As stated in the "Systems theory", basic features of the system include structuredness, interconnection of components of the system and orientation of the whole system to a specific aim. In addition to it, systems theory puts a special emphasis on observing the transformation of input signals into output ones [1-7].

The other component, required to solve the defined problem, is the process theory. According to the process theory, which in fact is one of the sections of mathematical theory of programming, the same behaviour may be the result of different processes, reflecting different abstraction levels of developing models of those behaviour and different levels of specification of actions, exercised by that system.

So, any company may be characterized by the same features, which gives an opportunity to regard it as a dynamic system, possessing unique specifications, such as constant temporal development and changes in system composition and in connections between components of the system while keeping the main functions of it. Besides, any company regard the processes, which have gateways, need to change some actions, and process outcomes (actions, which were already changed), as input and output signals. It means that any company must be dynamically stable. Bertalanffy's systems theory has a high value as, while investigating the issue of dynamic stability of the system, it studies influence not only of the system as a single entity, but also of its components (actions). In case of companies, processes-flows are a set of sequential actions, taken in order to achieve any result serving as the components of those systems. However, studying company as the system with complex rules of existence is based not only on the similarity of describing features and their decomposition, but also on the mode of operation and management of that system's material flows [69].

\section{MODELING OF STAGES OF INTEGRATED PLATFORM'S DEVELOPMENT}

To form a conceptual framework of process consistency, it is necessary to revise all available alternatives for system decomposition. For this purpose, the authors once again refer to the systems theory. The main problem of decomposition is the absence of univocal correspondence between the law of subsystems functioning and its implementation procedure. There are different models of decomposition. If one systematizes different views on systems theory [6], one will construct a conceptual framework of systems decomposition models (Fig. 1). 


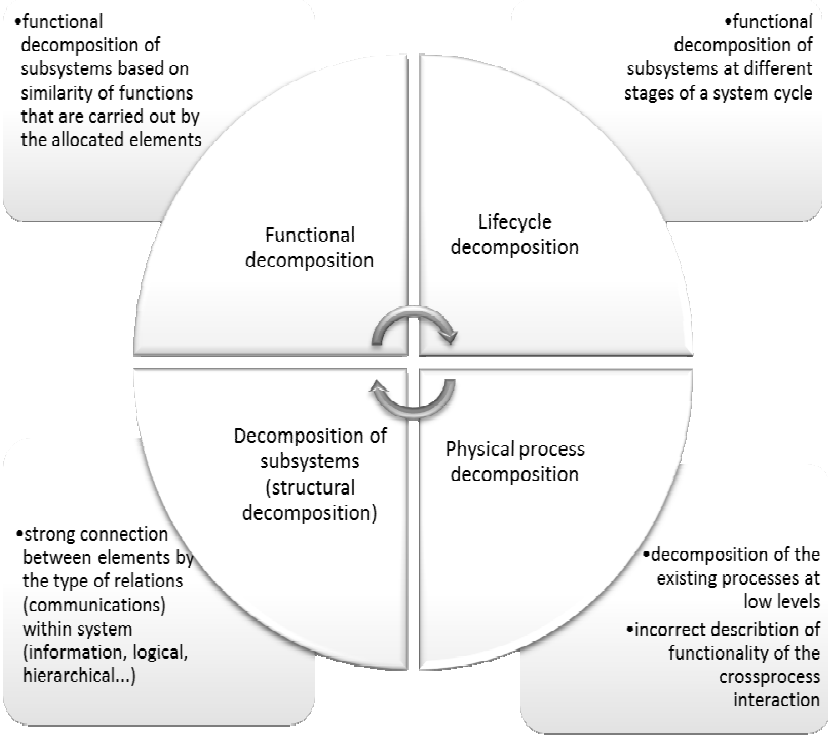

Fig. 1. Framework of systems decomposition models of material flows.

According to the systems theory, every system should be managed and predictable. If system with such characteristics is required, it is necessary to specify the points of control, which help to manage the system and predict its further development by increasing the system response. Such operationality provides dynamic stability of the system. In order to increase the dynamic stability and, as a result, to get the system with high system response, it is important to have controlled system and to understand its potential. In this case organizational principles of Bertalanffy's system theory are required, while the process theory is used for choosing types of processes. In reference to companies such processes as engineering and reengineering are applied.

Engineering and reengineering of processes imply identification and further modeling of processes on the basis of existing classification and software (notations) [7-14].

So, organizational system as well as every existing system should be managed and, as far as possible, traceable, i.e. dynamically stable. What is the connection between the organizational system and its dynamic stability? Dynamic stability is a capability of the system to recover after grand disturbance, when the synchronous mode of the system disrupts and then recovers after acceptable break. However, dynamic stability makes it possible to describe processes, emerging as a result of recessionary changes in a market, and provides an opportunity for elaboration of efficient measures, helping companies to keep and strengthen their positions on the market.

Of course, we do not neglect management methods, applied in every company, including methods, based on the use of control parameters (points). We would like to point out that a lot of managers understand through insight that company's stability and successful development rests upon the management system. As a result, it is possible to shape an integrated system of processes by consolidating all the abovementioned factors.

At that stage, one may face misunderstandings and erroneous modeling of the system. To develop the system, decomposed on the processes-flows (further - processes), it is essential to take into account the dynamic component of the system, i.e. all the actions, included into the process-flows (entry-, output and internal actions). Otherwise, modeling of the processes (and the system on the whole) will be senseless and inviable. It is also important to understand the concept of decomposition on the processes and specification of control tests of those processes. Nowadays there are many methods and instruments for controlling and modeling processes, based on different metrics. However, there is no clear and single understanding of consistency, as "sequential and predictable results may be reached more effectively and efficiently, when the activity is realized and managed as interdependent processes, functioning as a harmonized system" [14-17].

Every presented model of decomposition (fig.1) is quite viable. All of them are used for describing processes both as separate entity and as the combination of models. However, apart from choosing model of decomposition, decomposed processes should be described to shape a full model of company's system. Specialists usually apply three types of describing processes: textual description with the use of natural language; matrix representation, containing characteristics of processes as well as characteristics of input/output objects, which as a whole describe the model of system; graphical approaches in the form of developed functional models. During this study, the authors created a matrix of development and vitality of models of decomposition and types of description (Table 1):

TABLE I. CORRELATION BETWEEN MODELS OF DECOMPOSITION AND TYPES OF DESCRIBING PROCESSES

\begin{tabular}{|l|c|c|c|}
\hline \multirow{2}{*}{$\begin{array}{c}\text { Models of } \\
\text { decomposition }\end{array}$} & \multicolumn{3}{|c|}{ Types of describing processes } \\
\cline { 2 - 4 } & $\begin{array}{c}\text { Textual } \\
\text { description }\end{array}$ & $\begin{array}{c}\text { Matrix } \\
\text { representation }\end{array}$ & $\begin{array}{c}\text { Graphical } \\
\text { approach }\end{array}$ \\
\hline Functional & Low & High & High \\
\hline By the life cycle & Low & High & High \\
\hline $\begin{array}{l}\text { By the physical } \\
\text { procces }\end{array}$ & Low & Average & High \\
\hline $\begin{array}{l}\text { Structural } \\
\text { Lyyy }\end{array}$ & Low & Average & High \\
\hline
\end{tabular}

High efficiency - developed models have mobility, dynamism and response rates of functional response, close to the highest one.

Average efficiency - developed models have mobility, but it is difficult to take into account dynamic compomemts of the system while developing it, which decreases functional response.

Low effeciency - developed models do not have mobility, are hard to understand, which results in the loss of dynamic components of the system and a reduction of functional response to its minimum.

Table 1 shows that graphical approaches of the modeling company's system are the most effective ones. This approach helps to make developed models look like an integrated, easy traceable system. Such model describes how the company 
works as a whole and how the activity of every employee is organized. Processes of this model are well traceable: entry, output and internal actions (which are responsible for the dynamic component of the system as a whole) are well marked, which promotes easy optimization, engineering and reengineering of processes. However, despite all the advantages, this approach is not an ideal, as it has a number of drawbacks [17-19].

Integrated systems are best suitable for describing companies' dynamic systems, both for description of processes and system decomposition on different levels. To the authors' opinion, the most effective integrated platform of describing processes is the model, based on the matrix representation and graphical approach. Models development, based on such integrated platform, passes through a number of stages (Fig. 2).

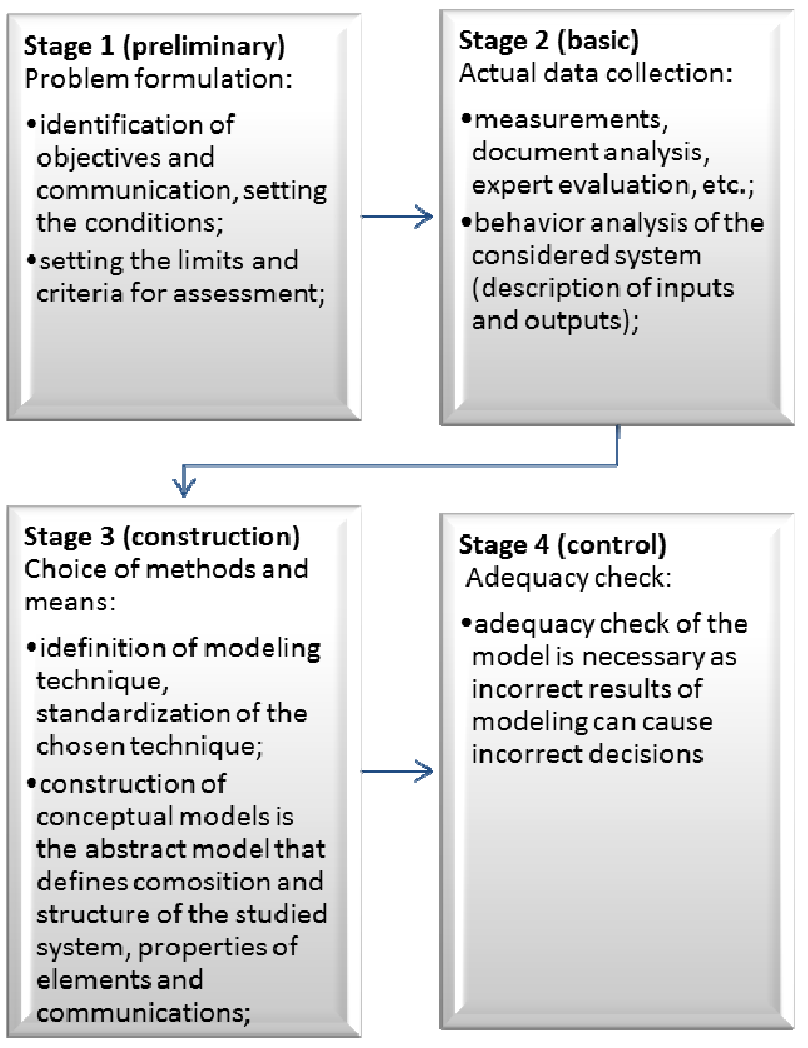

Fig. 2. Stages of creation of the integrated model

It is easy to note that first two stages represent development of the matrix form of process modeling and the third one is an example of the graphical approach.

\section{ADAPTATION OF INTEGRATED PLATFORM OF MODELING SYSTEM PROCESSES}

Modeling of processes, depending on the aims of modeling, may be divided into two categories: "AS-IS" and "TO-BE" models. The vitality of system models, based on the integrated platform, was confirmed in the one of the leading industries of the Far Eastern Federal District. The development of the model was conducted according to the stages, which were mentioned above. The identification of the processes, specification of inputs and outputs, suppliers and consumers, recourses and normative documents, regulating the activity of the company, were conducted during the first two stages. The results are presented in Tables II, III and IV.

TABLE II. IDENTIFICATION OF PROCESSES, INPUTS AND OUTPUTS, ETC. OF THE "AS-IS" MODEL.

\begin{tabular}{|c|c|c|}
\hline Flows & Input & Output \\
\hline 1 & 2 & 3 \\
\hline $\begin{array}{l}\text { 1. Analysis of } \\
\text { applications for } \\
\text { work } \\
\text { verification of } \\
\text { SI }\end{array}$ & $\begin{array}{l}\text { 1) Application (basic form } \\
\text { - SI lists, subject to } \\
\text { verification (calibration)); } \\
\text { 2) The SI list included in } \\
\text { the field of accreditation }\end{array}$ & $\begin{array}{l}\text { 1) Schedules of SI testing } \\
\text { for the year by types of } \\
\text { measurements; } \\
\text { 2) Graphs of verification of } \\
\text { SI, verified by its own } \\
\text { systems of the SGM } \\
\text { branch; } \\
\text { 3) Graphs of verification of } \\
\text { SI, which are subject to } \\
\text { verification by the forces } \\
\text { of the SGM of the MYFF, } \\
\text { or by the forces of the } \\
\text { SGM of another branch of } \\
\text { the Macroregion }\end{array}$ \\
\hline $\begin{array}{l}\text { 2. Content of } \\
\text { standards and } \\
\text { other SI }\end{array}$ & $\begin{array}{l}\text { 1) Standard and other SI; } \\
\text { 2) The list of SI included } \\
\text { in the field of accreditation }\end{array}$ & $\begin{array}{l}\text { 4) Calibration charts of } \\
\text { MC standards, as well as } \\
\text { SI workers not included in } \\
\text { the accreditation area }\end{array}$ \\
\hline $\begin{array}{l}\text { 3. Registration, } \\
\text { storage and } \\
\text { issue } \\
\text { verification } \\
\text { (calibration) } \\
\text { stamps }\end{array}$ & $\begin{array}{l}\text { Verifying } \quad \text { (calibrating) } \\
\text { hallmarks }\end{array}$ & \\
\hline $\begin{array}{l}4 . \quad \text { Handling } \\
\text { measurement } \\
\text { means that are } \\
\text { put into } \\
\text { calibration } \\
\text { (calibration) }\end{array}$ & Surrender of SI & \\
\hline
\end{tabular}

TABLE III. IDENTIFICATION OF PROCESSES - INPUTS OF THE “TO-BE” MODEL.

\begin{tabular}{|c|c|c|c|}
\hline Flows & Input & Suppliers & $\begin{array}{c}\text { Legen } \\
\text { d of } \\
\text { inputs }\end{array}$ \\
\hline 1 & 2 & 3 & 4 \\
\hline $\begin{array}{l}\text { 1. Analysis of } \\
\text { applications for } \\
\text { work } \\
\text { verification of } \\
\text { SI }\end{array}$ & $\begin{array}{l}\text { 1) Application (basic } \\
\text { form - SI lists, } \\
\text { subject to verification } \\
\text { (calibration)); } \\
\text { 2) The SI list } \\
\text { included in the field } \\
\text { of accreditation }\end{array}$ & Chief metrologist & IN - A \\
\hline $\begin{array}{l}\text { 2. Content of } \\
\text { standards and } \\
\text { other SI }\end{array}$ & $\begin{array}{l}\text { 1) Standard and other } \\
\text { SI; } \\
\text { 2) The list of SI } \\
\text { included in the field } \\
\text { of accreditation }\end{array}$ & $\begin{array}{l}\text { 1) External supplier } \\
\text { (manufacturer of } \\
\text { standards and other } \\
\text { SI); } \\
\text { 2) State Regional } \\
\text { Centers r for } \\
\text { Metrology of GRCM }\end{array}$ & IN - C \\
\hline
\end{tabular}




\begin{tabular}{|l|l|l|l|}
\hline $\begin{array}{l}\text { 3. Registration, } \\
\text { storage and } \\
\text { issue of } \\
\text { verification } \\
\text { (calibration) } \\
\text { stamps }\end{array}$ & $\begin{array}{l}\text { Verifying } \\
\text { (calibrating) } \\
\text { hallmarks }\end{array}$ & $\begin{array}{l}\text { External supplier } \\
\text { (manufacturer of } \\
\text { verification } \\
\text { (calibration) brands) }\end{array}$ & IN - P \\
\hline $\begin{array}{l}\text { 4. Handling } \\
\text { measurement } \\
\text { means that are } \\
\text { put into } \\
\text { calibration } \\
\text { (calibration) }\end{array}$ & Surrender of SI & Manager & \\
\hline
\end{tabular}

TABLE IV. IDENTIFICATION OF PROCESSES - OUTPUTS OF THE “TO-BE” MODEL.

\begin{tabular}{|c|c|c|c|}
\hline Flows & Output & Suppliers & $\begin{array}{l}\text { Legend } \\
\text { of inputs }\end{array}$ \\
\hline 1 & 2 & 3 & 4 \\
\hline $\begin{array}{l}\text { 1. Analysis of } \\
\text { applications for } \\
\text { works on } \\
\text { verification of } \\
\text { SI }\end{array}$ & $\begin{array}{l}\text { 1) Schedules of SI } \\
\text { testing for the year } \\
\text { by types of } \\
\text { measurements; } \\
\text { 2) Graphs of } \\
\text { verification of SI, } \\
\text { verified by the own } \\
\text { systems of the SGM } \\
\text { branch; } \\
\text { 3) Graphs of } \\
\text { verification of SI, } \\
\text { which are subject to } \\
\text { verification by the } \\
\text { forces of the SGM } \\
\text { of the MYFF, or by } \\
\text { the forces of the } \\
\text { SGM of another } \\
\text { branch of the } \\
\text { Macroregion; }\end{array}$ & $\begin{array}{l}\text { 1) Technical } \\
\text { Director } \\
\text { 2) Managers }\end{array}$ & OUT - A \\
\hline $\begin{array}{l}\text { 2. Content of } \\
\text { standards and } \\
\text { other SI }\end{array}$ & $\begin{array}{lr}\text { Provision } & \text { of } \\
\text { identifiable } & \text { and } \\
\text { registered standards } \\
\text { and other SI in } \\
\text { calibration } \\
\text { (calibration); }\end{array}$ & Metrological service & OUT - C \\
\hline $\begin{array}{l}\text { 3. Registration, } \\
\text { storage and } \\
\text { issue of } \\
\text { verification } \\
\text { (calibration) } \\
\text { stamps }\end{array}$ & $\begin{array}{l}\text { Assignment to each } \\
\text { vertex of personal } \\
\text { stigmas, having an } \\
\text { individual sign of a } \\
\text { witness }\end{array}$ & Metrological service & OUT - P \\
\hline
\end{tabular}

The third stage, graphical process modeling, may be carried out based on one of many different methodologies which are used nowadays. Programming software, introduced to market, creates models of process systems in the area of activity, necessary records, modeling of strategic aims, the balanced scorecard system, etc. The leading role among all of these technologies belongs to describing methodologies, based on SADT-Workflow and ARIS-technologies. Further, the authors will briefly describe each technology combining it with the results of their application in the company in this research [14-19].

Therefore, SADT-technologies belong to the structural approach of development of management systems, when the system is being hierarchically splitted in functional subsystems until it touches simple work. SADT-technology is a set of methods, rules and procedures, aimed at development of functional model of the object in the specific area.

While applying these technologies to the process modeling, an IDEF notations set, which includes such notations as IDEF0, IDEF1X, IDEF3, IDEF9, etc., and DFD notation are regarded as the basic ones [18-22]. The other notations set, Workflow, is focused on modeling of rules and demands, which should be followed during the operations. The basis of Workflow notations set consists of such notations as EPC, BPMN, Basic Flowchart, Cross Functional Flowchart etc. ARIS-technologies came from the sphere of creation of automatized information systems and may be regarded as a set of tools of analysis and modeling of company's activity. The process model may be elaborated with the use of different methodologies.

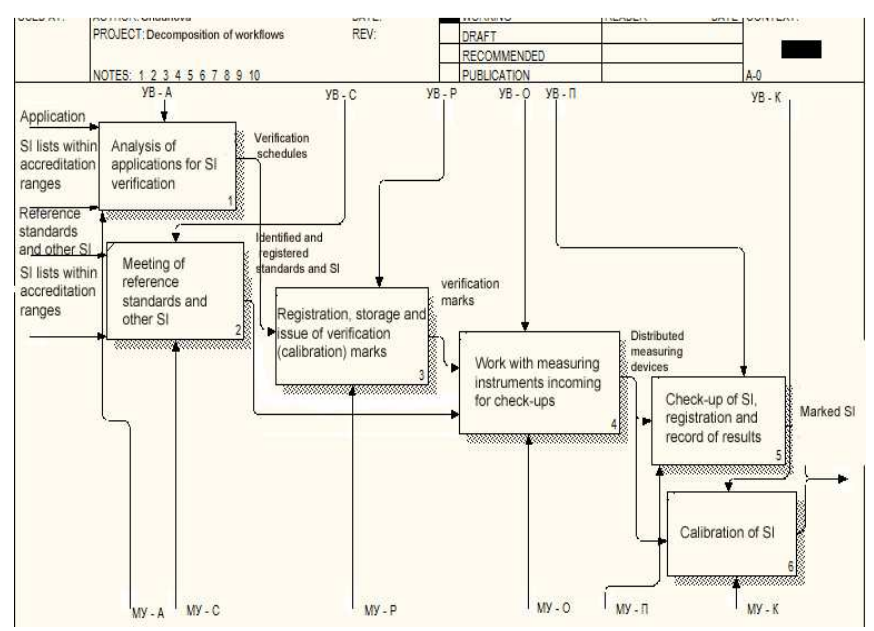

Fig. 3. Fragment model of material flows of the functional decomposition

Working with the case, the authors used SADT- and ARIS-technologies. Fragments of that developed model, based on the graphical approach, are given in Fig. 3 - 5.

The basic concept of working with ARIS-technologies is based on so-called "ARIS-House". ARIS methodology includes different notations for process modeling from different points of view. In this case, ARIS-House may be seen in Fig. 6.

These examples showed the advantages of the integrated platform, proposed by the authors for one of the leading manufactures of the Far Eastern Federal District, such as the fact that graphical information is situated in sight of the worker, textual information is transformed into image and supported by matrix in the form of specification. Now let us return to the process modeling in companies and evaluation of company's dynamic stability.

Therefore, process modeling is an effective tool for optimization of company's activity, which enables one to estimate how the company works as a whole and in every working position. 


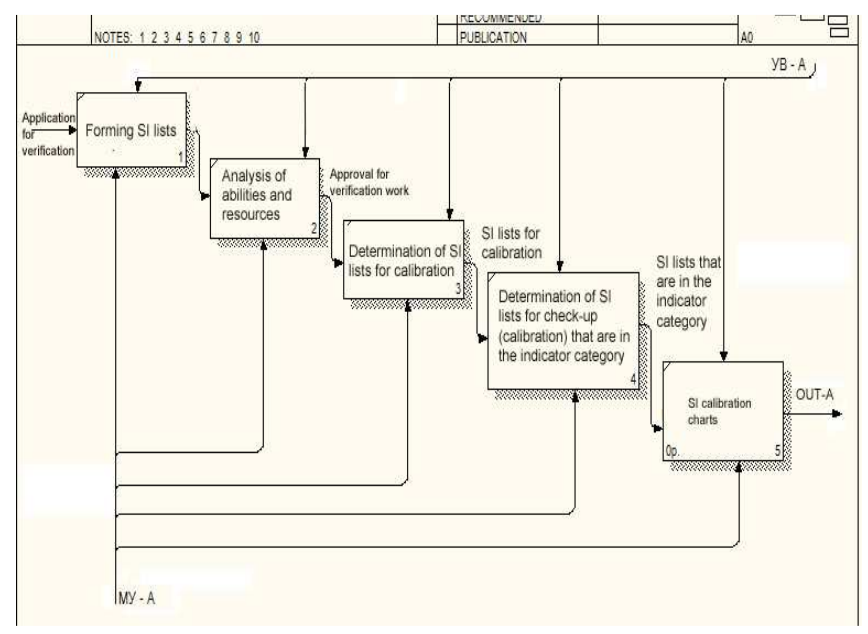

Fig. 4. Fragmentary model of material flows according to life cycle

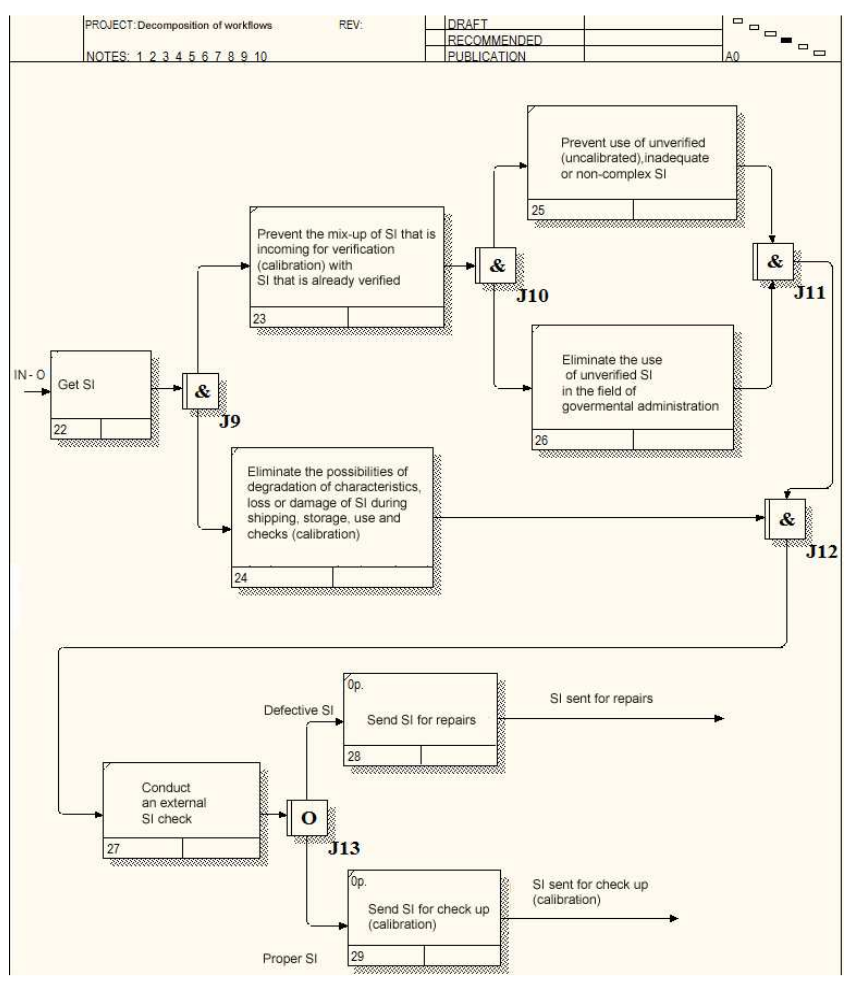

Fig. 5. Fragment of model of material flows of decomposition "By the physical procces "

It allows one to conduct the regulation of manufacturing processes that helps to define operational risks, to reduce loses and, as a consequence, to increase dynamic stability of the company.

If during the process modeling, the company increased its dynamic stability, it is necessary to reduce the time, needed for passing of information flow, in order to raise a functional response. Nowadays, it is hard to talk about the high functional response, as the majority of organizations become stuck in the vast amount of duplicate processes. To optimize the use of processes, modeled and regulated processes are united according to the principle of typification of technological processes, proposed by A. Sokolovsky in the sphere of machine manufacturing. This principle implies reducing the surplus of acting technological processes [16-19]. Among this, technological processes were organized in albums, technological and circulation maps. It is possible to use such method in reference to companies because technological process is an organized sequence of interdependent actions, conducted from emerging of input data to obtaining results.

ISO/TC 176/SC 2/N 544R3 defines the technological process as a set of interdependent and interacted types of activity, modifying inputs into outputs through a sequentially performed operation [23-29].

As both of these definitions are of the same type, the authors can recommend companies to proceed to the type of regulation, which is already known, i.e. models development in the form of albums, technological and circulation maps. Development of album of processes, based on the integrated platform of management, is an innovative technology, enabling companies to keep their competitive advantages, mobility, dynamic stability and a high functional response (Fig.6).

This developed model is based on the integrated platform of process modeling and constructed according to the principles of albums of flow charts, build by Standard 3.110982 [23, 30-35].

\section{CONCLUSION}

The created album of processes provided an opportunity to reduce risks, increase the level of internal control and make processes more designable and predictable, i.e. to raise their functional response. The album of processes, offered to the company, raises its operational efficiency, cuts duplicate flows and defines the control points of the processes. When company has a model of an organization and of its processes, which have specific goals, it may be self-improved. Company's model will enable to conduct a full analysis from all perspectives and find out something, which was not noticed before. Moreover, the model, based on the integrated platform, may be easily strengthened by the mathematical simulation, with implementing new factors, such as KPI, ABC and balanced scorecards, which allows not only tracing the activity of modeled process, but also predicting its further behaviour.

\section{References}

[1] T. Shkarina, O. Chudnova and O. Mokhova "Comparative study on economic security of enterprises depending on implemented business activities quantity". SHS Web of Conferences, Vol. 35, June 2017 [3rd International Conference on Industrial Engineering (ICIE-2017) https://doi.org/10.1051/shsconf/20173501075, 2017].

[2] T.Yu. Shkarina, "Economic analysis of the quality management system to a diversified enterprise" Economics and Management: Research and Practice Journa. UFA, vol. 1, p.102. 2010.

[3] M. Bonney, M.Y. Jaber "Deriving research agendas for manufacturing and logistics systems: A methodology", International Journal of Production Economics, vol.. 157, pp. 49-61, 2014. 


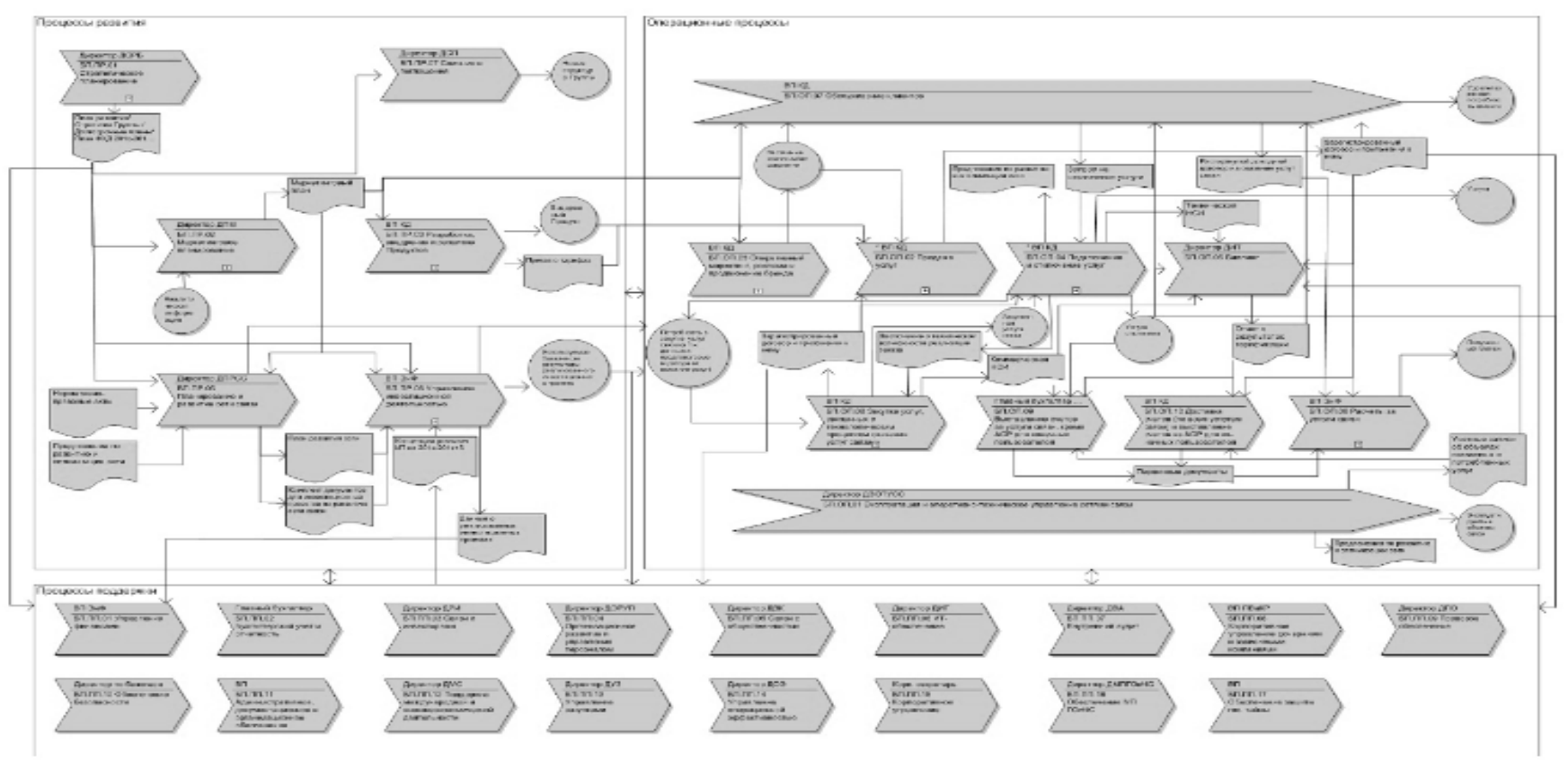

Fig. 6. "ARIS House" offered for the enterprise

[4] N. Sidorova, Ir. Repina and V. Timchenko "Priority directions of innovative development of Russian fuel and energy complex on global investment market", SHS Web of Conferences, Vol. 35, June 2017 [3rd International Conference on Industrial Engineering (ICIE-2017) https://doi.org/10.1051/shsconf/20173501066, 2017].

[5] Yu.Sidorenko, V.G. Frolov, N.A. Salmina "Main characteristics and features of logistics systems for materials flow management in industrial production", Vestnik of Lobachevsky State University of Nizhni Novgorod. Series: Social Sciences, vol. 2, pp. 63-72, 2016.

[6] L. Bertalanffy "General System Theory - A Critical Review", General Systems, vol. VII, pp. 1-20, 1962.

[7] L. Bertalanffy, System Research: Yearbook, vol. 23, 1969.

[8] ISO 9000 Introduction and Support Package: Guidance on the Concept and Use of the Process Approach for management systems [Online]. Available: http://www.iso.org/iso/ru/

[9] B. Andersen. Business processes, Tools of perfection, 2003.

[10] M. Eliyahu Goldratt. The Goal: A Process of Ongoing Improvement, 2rd ed, 2008.

[11] M. Eliyahu Goldratt. It's Not About Luck, 2rd ed, 2011.

[12] M. Eliyahu Goldratt. Necessary, but not suffucient, 1rd ed, 2009.

[13] B. Andersen Business processes. Tools for improving, 2005.

[14] Methods for implementing the process approach. The series "All about quality. Domestic developments, 2002.

[15] S.M. Kovalev, S.M. Kovalev, "Modern methodologies and standards for describing business processes: advantages, disadvantages and applications", Reference book of economist, vol. 11, 2006.

[16] A. Sokolovsky "Process Automation metal machining", Avtom. i Telemekh., vol. 3, pp.117-139, 1938.

[17] V. Repin, V. Eliferov, Process approach to management. Modeling business processes, 2013.

[18] O. Fedorova "The use of rational ROSE AND ARIS CASEtechnologies in business processes modelling", Herald of "TISBI", vol. 2, p.166-172, 2013.

[19] V.V. Yudin, O.A. Chudnova "The generalized reshetochny systems as sverkhperkoliruyushchy structures", Bulletin Of The Russian Academy Of Sciences: Physics, vol. 10, pp. 1405-1410, 2001.
[20] V.V. Yudin, O.A. Chudnova "Penrose mosaic as a quasistochastic treegraph lattice", Journal of Crystallography Reports, vol. 47(2), pp.189195, 2002.

[21] V.R. Susov, A.N. Samaden Vijavlenije I ustanovljenie uzkih mest v biznes-prozessah organizazii [The identification and establishment bottlenecks in the business processes of the organization], Nauka I biznes: puti razvitija, vol. 10 (128), pp. 131-137, 2013.

[22] J. Richard Mayer, K. Michael Painter, Madhavi Lingineni, Information integration for concurrent engineering toward a method for business constraint discovery (IDEF9), 1995.

[23] GOST 3.1109-82 Unified system for technological documentation. Terms and definitions of main concepts, 2012.

[24] E.Börger, R.Staerk Abstract State Machines: A Method for High Level System Design and Analysis [Berlin: Springer - Verlag, 2003]

[25] Academic Dictionaries and Encyclopedias. http://dic.academic.ru

[26] L.R. Batukova "Features of formation of process organizational structure of the average versatile enterprises of corporate type", Journal of Vestnik of SibGAU,vol. 2(15), pp.110, 2007.

[27] K. Berg, Theory of graphs and its applications, 1962.

[28] R. Diestel, Graph Theory, Electronic Edition, Springer-Verlag, NY, 2005.

[29] V.L. Sharstnyov, E.Yu. Vardomatskaya "Implementation of network planning methods and management", Management of economic systems, vol. 05, 2006.

[30] GOST R 56716-2015 Project management. Project network techniques. Descriptions and concepts. http://docs.cntd.ru/document/1200127270

[31] GOST R 21500-2014 Guidance on project management. http://docs.cntd.ru/document/1200118020

[32] E. Börger, R. Staerk, Abstract State Machines: A Method for High Level System Design and Analysis, Springer - Verlag, Berlin, 2003.

[33] I.G. Abramova, Project management based on network models, Samar. State. Aerospace. Un-t, Comp, 2007.

[34] V.N. Burkov, D.A. Novikov, Theory of graphs in the management of organizational systems, 2001.

[35] M.A. Korotkov, Methods of network planning, 2003. 